\title{
PENGEMBANGAN MODUL PENDIDIKAN ANTI KORUPSI PADA MATA PELAJARAN PENDIDIKAN PANCASILA DAN KEWARGANEGARAAN UNTUK KELAS X \\ SEKOLAH MENENGAH ATAS
}

\author{
Sutrisno, Mukhamad Murdiono \\ Universitas Muhammadiyah Ponorogo, Universitas Negeri Yogyakarta \\ sutrisno.afiq@gmail.com, mukhamad_murdiono@uny.ac.id
}

\begin{abstract}
Abstrak
Penelitian ini bertujuan untuk menghasilkan: (1) Modul pembelajaran pendidikan antikorupsi sebagai sumber belajar yang layak untuk peserta didik SMA kelas X, (2) Modul pendidikan antikorupsi yang efektif pada hasil belajar peserta didik di SMA, (3) Modul pendidikan antikorupsi yang efektif pada sikap antikorupsi peserta didik di kelas X. Penelitian ini merupakan model penelitian dan pengembangan (research and development). Berdasarkan hasil penelitian menunjukkan bahwa: (1) dihasilkan modul pendidikan antikorupsi yang layak sebagai sumber belajar pada mata pelajaran PPKn kelas X; (2) modul pendidikan antikorupsi yang efektif untuk meningkatkan hasil belajar peserta didik di SMA. Hal ini ditunjukkan dengan perolehan gain score dan meningkatnya nilai mean; (3) modul pendidikan antikorupsi yang efektif untuk meningkatkan sikap antikorupsi peserta didik di SMA. Hal ini ditunjukkan dengan perolehan gain score dan meningkatnya skor mean.
\end{abstract}

Kata kunci: modul, pendidikan antikorupsi, pendidikan pancasila dan kewarganegaraan

\section{DEVELOPING ANTI-CORRUPTION EDUCATION MODULE IN THE SUBJECT OF PANCASILA AND CIVICS EDUCATION OF HIGH SCHOOL STUDENTS GRADE X}

Sutrisno, Mukhamad Murdiono

Universitas Muhammadiyah Ponorogo, Universitas Negeri Yogyakarta sutrisno.afiq@gmail.com, mukhamad_murdiono@uny.ac.id

\begin{abstract}
This research aims to produce: (1) anti-corruption education learning modules for high school students grade $X,(2)$ anti-corruption education modules that effectively improve the learning outcomes of students in high school, and (3) anti-corruption education modules that effectively improve the anti-corruption learners in grade $X$. This research model is research and development $(R \& D)$ based. The following conclusions were drawn from the research results: (1) The development results in anti-corruption education modules in subjects Pancasila and Civics Education in grade $X,(2)$ anti-corruption education modules are affective to improve learning outcomes of students in high school as evidenced by the acquisition gain score and an increase in the mean value, (3) anti-corruption education modules are affeetive to improve the anti-corruption attitudes of high school students. This is evidenced by the acquisition gain score and an increase in the mean score.
\end{abstract}

Keywords: module, anti-corruption education, pancasila and civics education 


\section{Pendahuluan}

Pendidikan di Indonesia sedang menghadapi masalah besar terkait dengan tantangan globalisasi yang semakin meluas di segala aspek kehidupan, termasuk dalam dunia pendidikan. Tantangan globalisasi bukan saja dapat menjadi penyebab rendahnya kepemimpinan yang memiliki karakter Pancasilais dan moralitas dalam mengabdikan kepada bangsa. Berbagai persoalan yang terjadi di Indonesia saat ini memang tidak semudah membalikkan telapak tangan. Pemerintah sebagai elemen penting dalam penataan sistem hukum nasional belum dapat mewujudkan perannya secara optimal. Lembaga legislatif sebagai salah satu pembuat peraturan perundang-undangan justru belum dapat menjalankan peran dan fungsinya dengan baik, sedangkan peran dari lembaga yudikatif hanya sekedar penyempurna sistem peradilan saja.

Praktik korupsi menjadi masalah utama bagi bangsa Indonesia, wujudnya menyebar di berbagai elemen kehidupan masyarakat. Tentunya tidak heran bahwa praktik korupsi terjadi dari hilir hingga menjalar ke muara di setiap proyek budgeting. Data Indonesia Corruption Watch (ICW) mengambarkan sepanjang semester satu tahun 2013, terdapat 293 khasus korupsi, dengan 597 orang tersangka. Dari 293 khasus, 114 diantaranya merupakan khasus pengadaan barang dan jasa (PBJ) atau 46,38 persen, dengan 314 tersangka. Sedangkan untuk semester dua ditemukan ada 267 kasus korupsi dengan 594 tersangka, dan 42,7 persennya adalah PBJ. Lebih dari itu hingga Desember 2013 sudah 311 kepala daerah yang terkait masalah-masalah hukum (Mukodi \& Buhanuddin, 2014, p. 25). Sedangkan menurut hasil dari Transparency International, institusi non-partisan yang berbasis di Berlin (Jerman) menerbitkan indeks persepsi korupsi tahunan berdasarkan polling yang menilai sejauh mana korupsi dianggap terjadi di kalangan pejabat publik dan politisi di semua negara seluruh dunia.

Indeks persepsi korupsi di Indonesia pada Tahun 2015 menunjukkan hasil kota yang memiliki skor tertinggi dalam Indeks Persepsi Korupsi adalah Kota Banjarmasin dengan skor 68, Kota Surabaya dengan skor 65, dan Kota Semarang dengan skor 60. Sementara itu, Kota yang memiliki skor Indeks Persepsi Korupsi terendah adalah Kota Ban- dung dengan skor 39, Kota Pekanbaru dengan skor 42, dan Kota Makassar skor 48. Dari hasil survei didapati bahwa responden menilai adanya perbaikan tata kelola pemerintahan yang baik di lembaga-lembaga pemerintahan, namun komposisi sektor publik yang dipersepsikan korup masih sama. Responden masih menilai kepolisian, legislatif, dan peradilan sebagai sektor publik yang paling terdampak oleh korupsi

Secara harfiah korupsi dapat diartikan sebagai kebusukan, keburukan, kebejadan, ketidakjujuran, dapat disuap, tidak bermoral, penyimpangan dari kesucian. Memperkaya diri sendiri dengan cara yang tidak benar merupakan gambaran umum dari pengertian korupsi. Banyak definisi yang menjelaskan arti dan makna dari korupsi, salah satunya Klitgaard (Svensson, 2005, p. 29) menyatakan bahwa "ajakan dari seorang (pejabat) dengan pertimbangan-pertimbangan yang tidak semestinya. Definisi yang luas ini menyangkup sebagian besar kegiatan haram yang ditemukan oleh hakim di dalam BIR (biro pendapatan dalam negeri).

Ada beberapa unsur-unsur yang melatar belakangi terjadinya korupsi. Menurut (Van Dyne \& LePine, 1998) unsur-unsur tersebut meliputi

(1)a person with the authority (powers) to adopt decisions that are relevant to society. (2) legal norms regulating decisionmaking (legislation, principles, criteria, procedures. (3) a person or persons seeking a decision that is favourable to them. (4) mutually benefi cialex change between adecision-makeran dapersonor persons seeking this decision. (5) violated decisionmaking norms, damage caused to society

Dengan demikian, dapat diartikan bahwa seseorang yang memiliki kekuasaan sangat mudah untuk mengambil keputusan yang terkait dengan rakyat, kemudian berdampak dalam pengambilan keputusan berupa undang-undang dan peraturan hukum yang meliputi prinsip, kriteria dan prosedur dalam pengambilan keputusan yang tidak sesuai dengan kebutuhan rakyat akan tetapi dimanfaat demi kepentingan pribadi atau kelompok.

Pembentukan dasar hukum pemberantasan korupsi sudah sangat jelas dan sudah diterbitkan baik dari hukum meteriil mapun dari segi hukum formil, antara lain Ketetapan MPR No. XI/MPR/1998 (Republik Indonesia, 
1998) tentang Penyelenggaraan Negara yang Bersih dan Bebas Korupsi, kemudian ditegaskan kembali dengan Undang-Undang RI Nomor 8 Tahun 1999 (Republik Indonesia, 1999) tentang Penyelenggara Negara yang Bersih dan Bebas dari Korupsi, Kolusi, dan Nepotisme. Sedangkan untuk menindaklanjuti adanya undang-undang tentang korupsi maka dibentuklah Komisi Pemberantasan Korupsi (KPK) yang diatur dalam Undang Undang RI Nomor 30 Tahun 2002 (Republik Indonesia, 2002) tentang Komisi Pemberantasan Tindak Pidana Korupsi.

Dasar hukum tersebut tentunya dapat dijadikan rujukan atau acuan dalam pemberantasan berbagai tidak pidana korupsi yang ada di Indonesia. Namun tidak sebatas hanya produk hukum semata yang harus diperbaiki tetapi juga peran serta masyarakat dalam mengimplementasikan berbagai peraturan tersebut, baik dari lingkungan keluarga, pendidikan, dan masyarakat, khususnya pada lingkungan pendidikan. Hal inilah yang kemudian mendorong KPK untuk menanamkan nilai-nilai dan prinsip-prinsip antikorupsi sedari dini. Dalam rencana KPK tahun 20082011 tergambar bahwa salah satu sasaran untuk bidang pencegahan adalah pembentukan budaya masyarakat antikorupsi, melalui pendidikan yang profesional baik sektor formal maupun informal secara bertahap.

Saat ini pendidikan antikorupsi pada jenjang Sekolah Menengah pada kurikulum 2013 sudah diupayakan muatan materi tentang pendidikan antikorupsi, akan tetapi dalam buku guru dan buku siswa belum ada kompetensi dasar atau sumber belajar yang memuat materi pendidikan antikorupsi baik di kelas $\mathrm{X}$ maupuan XI. Tentu hal ini akan berdampak pada rendahnya sikap, pengetahuan dan keterampilan peserta didik tentang materi Pendidikan Antikorupsi.

Pada dasarnya pendidikan anti korupsi dapat diartikan sebagai salah satu program pendidikan yang menjelaskan dan menanggulagi berbagai korupsi yang terjadi di kalangan masyarakat dengan upaya penanaman sedini mungkin jiwa antikorupsi dengan tujuan untuk membangun dan meningkatkan kepedulian warga engara terhadapa bahaya dan akibat dari tindakan korupsi. Pendidikan antikorpusi memiliki 3 tujuan. Pertama, membentuk pengetahuan dan pemahaman bentuk korupsi dan aspek-aspeknya. Kedua, mengubah per- sepsi dan sikap terhadap korupsi. Ketiga, membentuk keterampilan dan kecakapan baru yang ditujukan untuk melawan korupsi (Hakim, 2012, p. 7).

Pendidikan antikorupsi tentu mengembangkan nilai-nilai dasar sikap antikorupsi. secara umum sikap adalah "an attitude was defined as a prefence along a dimension of favorableness to unfavorableness to a particular group, institution, concept, or object" (Sax, 1993, p. 493). Hal ini dapat diartikan bahwa sikap merupakan kecenderungan dari berbagi sikap yang disukai maupun tidak disukai pada kelompok, konsep, institusi dan objek tertentu. Sikap dan karakteristik dari individu akan selalu mengambarkan sikap positif dan negatif terhadap objek, situasi, institusi, atau ide tertentu. Peserta didik yang memiliki sikap positik akan lebih berminat dalam proses pembelajaran di kelas lebih mudah diberi motivasi dan lebih mudah menyerap setiap materi yang disampaikan

Sebagai salah satu sarana dalam penerapan nilai-nilai dan prinsip-prinsip antikorupsi menurut Nanag \& Romie (Mukodi \& Buhanuddin, 2014, p. 38) di jelaskan bahwa ada sembilan nilai-nilai sikap antikorupsi yang harus dikembangkan yakni sikap kejujuran, kepedulian, kemandirian, kedisiplinan, tanggung jawab, kerja keras, sederhana, keberanian, dan keadilan. Dari kesembilan sikap tersebut tentu juga dikembangkan di berbagai negara-negara di dunia dengan konsep dan sistem yang berbeda akan tetapi memiliki tujuan yang sama yakni menanamkan jiwa antikorupsi pada setiap warga negara agar terwujud tatanan negara yang bebas akan tindak pidana korupsi.

Banyak media pembelajaran yang dapat di gunakan untuk mengimplementasikan materi pendidikan antikorupsi pada peserta didik. Hal ini tentu seperti yang dinyatakan Murwantono \& Sukidjo (2015, p. 33) bahwa media pembelajaran sangat bervariasi, namun kenyataannya penggunaan media pembelajaran membosankan dan kurang variatif. Dalam pengembangan pembelajaran, salah satu tugas guru adalah memilih media pembelajaran yang digunakan membantu siswa peserta didik mencapai kompetensi yang dinginkan.

Pendidikan antikorupsi dapat diterapkan melalu sumber belajar yakni modul pembelajaran. merupakan satu unit kegiatan pembelajaran di kelas yang didalamnya memuat 
berbagai komponan baik itu tujuan, topik, pokok-pokok materi, peranan guru, alat-alat dan sumber belajara, kegiatan belajar, lembar kerja maupun evaluasi (Vembriarto, 1985, p. 29). Modul pendidikan antikorupsi tersebut tentu dapat dikembangkan dalam mata mata pelajaran PPKn. Mata pelajaran PPKn menurut Mohammad Nuh dalam pengantar buku Guru PPKn SMA (Depdiknas, 2014, p. iii), menjelaskan bahwa mata pelajaran Pendidikan Pancasila dan Kewarganegaraan adalah mata pelajaran yang dirancang untuk membekali peserta didik dengan keimanan dan akhlak mulia sebagaimana diarahkan oleh falsafah hidup bangsa Indonesia yaitu Pancasila. Melalui pembelajaran PPKn, peserta didik dipersiapkan untuk dapat berperan sebagai warga negara yang efektif dan bertanggung jawab. Tinjauan pedagogik, Pendidikan Pancasila dan Kewarganegaraan (PPKn) merupakan bidang kajian keilmuan, program kurikuler, dan aktivitas sosial-kultural yang bersifat multidimensional. Sifat multidimensional ini menyebabkan Pendidikan Pancasila dan Kewarganegaraan dapat disikapi sebagai pendidikan nilai dan moral, pendidikan kemasyarakatan, pendidikan kebangsaan,pendidikan kewarganegaraan, pendidikan politik, pendidikan hukum dan hak asasi manusia, serta pendidikan demokrasi.

Melihat adanya sifat multidimensional pada mata pelajaran Pendidikan Pancasila dan Kewarganegaraan, maka pelajaran PPKn merupakan salah satu media yang efektif dan efisien dalam mentransformasikan nilai-nilai dan prinsip-prinsip antikorupsi pada generasi muda melalui pendidikan antikorupsi di lingkungan sekolah dengan harapan materi pendidikan antikorupsi mampu menjadi tolak ukur untuk meningkatkan hasil belajar peserta didik dan merupakan wujud dalam penanggulangan korupsi di Indonesia.

Salah satu hal yang juga mendasari pembuatan modul pendidikan antikorupsi adalah menurunnya sikap, pengetahuan dan keterampilan peserta didik. Tentu hal ini dibuktikan dengan rendahnya sikap dalam berperilaku yang mencerminkan nilai-nilai dasar antikorupsi. berdasarkan data observasi di Kabupaten Ponorogo menunjukkan bahwa banyak siswa yang berbohong ketika sekolah ada program kantin kejujuran. Serta banyaknya laporan orang tua wali murid pada sekolah tentang keterlambatan pembayaran uang sekolah yang faktanya sudah diberikan kepada anak ternyata oleh anak yang bersangkutan uang pemberayaran tersebut belum tersampaikan pada pihak sekolah, hal ini mayoritas terjadi di Sekolah Menengah Atas di Kabupaten Ponorogo. Sikap tersebut tentu juga dipengaruhi oleh tingkat pengetahuan dan keterampilan yang diserap oleh peserta didik pada materi pendidikan antikorupsi yang masih rendah.

Pengembangan modul pendidikan antikorupsi merupakan langkah awal dalam penyempurnaan media pembelajaran sebagai sumber belajar khususnya dalam penanaman jiwa anti korupsi pada generasi muda guna meningkatkan kemampuan pengetahuan yang dilihat dari hasil belajar serta sikap dan keterampilan antikorupsi peserta didik. Modul yang diperlukan dalam pembelajaran pendidikan antikorupsi berupa kompetensi, materi, strategi, media, evaluasi dan sumber belajar. Penerapan pendidikan antikorupsi bukan merupakan hal yang mudah untuk diterapkan, akan tetapi membutuhkan proses dan waktu. Dengan adanya proses secara sistematis akan memudahkan penanaman nilai-nilai antikorupsi pada peserta didik yang akhirnya akan menjadi budaya antikorupsi pada lingkungan sekolah, keluarga, masyarakat, bangsa dan negara.

Dari latar belakang tersebut peneliti tertarik untuk melakukan penelitian pengembangan pada peserta didik di SMA Muhammadiyah 1 Ponorogo untuk menerapkan langsung contoh modul pendidikan antikorupsi pada mata pelajaran PPKn dalam upaya peningkatan hasil belajar dan sikap antikorupsi.

Penelitian pengembangan ini diharapkan mampu menjadi media dan anternatif dalam penanaman nilai-nilai dan prinsipprinsip antikorupsi pada peserta didik yang efektif, inovatif dan mudah diterapkan dalam pembelajaran di kelas melalui modul pendidikan antikorupsi. Dengan demikian mampu mengendalikan dan mengurangi korupsi dalam upaya untuk mendorong generasi muda untuk mengembangkan sikap menolak secara tegas terhadap setiap bentuk korupsi.

Berdasarkan urain yang disampaikan tersebut, maka penelitian ini bertujuan untuk Penelitian ini bertujuan untuk menghasilkan: (1) modul pembelajaran pendidikan anti-korupsi sebagai sumber belajar yang layak untuk peserta didik SMA kelas X, (2) modul pendidikan antikorupsi yang efektif pada hasil belajar peserta didik di SMA, (3) modul pendi- 
dikan antikorupsi yang efektif pada sikap antikorupsi peserta didik di kelas X.

\section{Metode Penelitian}

Model penelitian ini adalah model penelitian dan pengembangan (research and development). Adapun model pengambangan yang dilakukan yakni menggunkan model pengembangan perangkat Four-D Model yang disarankan oleh Thiagrajan, Dorthy, dan Melvyn (1974.P.4). Dengan kata lain model tersebut diadaptasikan menjadi 4-D yaitu pendefinisian, perencangan, pengembangan, dan penyebaran.

Penelitian ini dilaksanakan di SMA Muhammadiyah 1 Ponorogo pada kelas X Awas semester 2. Desain uji coba penelitian dibagi menjadi 2 tahap. Tahap pertama adalah validasi oleh subjek perorangan (reviewer internal dan eksternal). Tahap kedua adalah uji coba pada kelompok kecil dan uji lapangan. Subjek penilaian ini dibagi menjadi tiga kelompok yaitu reviewer internal dan reviewer eksternal dan peserta didik untuk uji coba. Subjek penilaian pada kelompok kecil dilakukan terhadap peserta didik yang mempunyai kualifikasi memiliki nilai rata-rata nilai ulangan harian PPKn tertinggi, sedang, dan terendah dikelasnya. Sedangkan subjek penilaian pada uji coba lapangan dilakukan pada kelas $X$ IPA 3 yang memiliki rata-rata nilai ulangan harian PPKn tertinggi. Dalam penelitia ini terdapat dua jenis data, data primer yang menilai kelayakan modul dan data sekunder yang menilai efektifitas hasil belajar dan sikap antikorupsi peserta didik.

Adapun instrumen yang digunakan dalam penelitian ini adalah angket, soal test (post-test, pre-test), dan lembar observasi. Teknik analisis data untuk melihat kelayakan modul dilakukan dengan langkah-langkah sebagai berikut: Pertama, tabulasi semua data yang diperolah dari masing-masing validator dari masing-masing komponen, sub komponen dari butur penilaian yang tersedia dalam instrumen penelitian. Kedua, menghitung skor total rata-rata dari setiap komponen dengan menggunakan rumus:

$$
\mathrm{X}=\Sigma \mathrm{X} / \mathrm{n}
$$

Keterangan:

$\mathrm{X}=$ skor rata-rata

$\Sigma \mathrm{X}=$ jumlah skor

$\mathrm{n} \quad=$ jumlah penilai
Ketiga, mengubah skor rata-rata menjadi nilai dengan kriteria.

Sedangkan Teknik analisis data untuk mengetahui efektifitas hasil belajar peserta didik dalam penelitian ini menggunakan teknik normalized gain score atau normalisasi skor gain $\langle\mathrm{g}\rangle$. Dengan mengetahui rata-rata nila (g) maka dapat diketahui peningkatan hasil belajar peserta didik dengan menggunakan modul pembelajaran yang digunakan. Pada Analisis sikap antikorupsi peserta didik dapat diperoleh dengan rumusan sebagai berikut:

Skor Maksimal $=$ Skor Tertinggi $\mathrm{x}$ Banyaknya Aspek $=45$

Nilai $=(($ jumlah skor yang diperoleh tiap peserta didik))/(skor maksimal) x 100

\section{Hasil Penelitian dan Pembahasan}

Modul pendidikan anti korupsi pada materi "Sistem Hukum dan Peradilan di Indonesia" yang telah dibuat oleh peneliti divalidasikan olah dua tipe reviewer, yaitu reviewer internal dan reviewer eksternal. Reviewer internal terdiri dari dosen ahli materi, dosen ahli media dan teman sejawat. Sedangkan untuk reviewer eksternal terdiri dari guru mata pelajaran PPKn dan perwakilan perserta didik kelas X untuk mengetahui respon peserta didik dalam penggunaan modul. Hasil dari review ini digunakan untuk merevisi modul pendidikan anti korupsi sebelum diujicobakan. Secara lebih detail dapat dijelaskan sebagai berikut.

\section{Data Reviewer Ahli Materi}

Validasi ahli materi dalam penelitian ini terdiri dari 3 aspek yaitu aspek komponen kelayakan isi materi, komponen pembelajaran, dan komponen bahasa. Aspek komponen kelayakan isi materi mengenai modul memiliki ketepatan dalam materi dan modul memiliki kesesuaian dengan penalaran peserta didik. Pada aspek komponen pembelajaran mengenai modul menjelaskan jenis pembelajaran. prinsip pembelajaran, strategi pembelajaran dan evaluasi pembelajaran. Sedangkan pada aspek komponen bahasa mengenai modul memiliki ketepatan dalam penggunaan bahasa. Berdasarkan hasil validasi ahli materi menunjukkan bahwa penilaian mengenai aspek komponen kelayakan isi materi yang ada pada modul pendidikan anti korupsi memperoleh 
jumlah skor sebesar 43. Dengan demikian penilaian ahli materi mengenai kelayakan isi materi dalam modul yang telah disusun termasuk kategori baik. Selanjutnya hasil validasi ahli materi pada aspek komponen pembelajaran 8 menunjukkan bahwa penilaian mengenai aspek komponen pembelajaran yang ada pada modul pendidikan anti korupsi memperoleh jumlah skor sebesar 75 . Penilaian ahli materi mengenai komponen pembelajaran dalam modul yang telah disusun termasuk kategori sangat baik. Berdasarkan hasil validasi ahli materi menunjukkan bahwa penilaian mengenai aspek komponen bahasa yang ada pada modul pendidikan anti korupsi memperoleh jumlah skor sebesar 23. Penilaian ahli materi mengenai komponen bahasa dalam modul yang telah disusun termasuk kategori sangat baik

\section{Data Reviewer Ahli Media}

Berdasarkan hasil validasi ahli media menunjukkan bahwa penilaian ahli media pada aspek komponen penyajian media teks yang ada pada modul pendidikan anti korupsi memperoleh jumlah skor sebesar 40 dalam kategori kurang baik. Selain aspek komponen penyajian media teks juga terdapat penilaian validasi ahli media pada aspek kegrafikan. Hasil validasi ahli media aspek kegrafikan pada tabel 11 dalam modul pendidikan anti korupsi memperoleh skor 45. Penilaian ahli media mengenai komponen kegrafikan dalam modul yang telah disusun termasuk kategori cukup baik.

\section{Data Reviewer Guru Mata Pelajaran PPKn}

Validasi reviewer guru mata pelajaran PPKn mencakup komponen kelayakan isi materi, komponen pembelajaran, komponen bahasa, komponen penyajian media teks, dan komponen kegrafikan. Berdasarkan hasil validasi reviewer guru mata pelajaran PPKn menunjukkan bahwa penilaian reviewer guru mata pelajaran PPKn pada aspek komponen kelayakan isi materi yang ada pada modul pendidikan anti korupsi memperoleh jumlah skor sebesar 42. Penilaian reviewer guru mata pelajaran PPKn pada aspek komponen kelayakan isi materi yang ada pada modul pendidikan anti korupsi termasuk kategori baik.

Selain aspek komponen kelayakan isi materi, juga terdapat penilaian validasi $r e$ - viewer guru mata pelajaran PPKn pada aspek komponen pembelajaran. Berdasarkan hasil validasi reviewer guru mata pelajaran PPKn menunjukkan bahwa penilaian mengenai aspek komponen pembelajaran yang ada pada modul pendidikan antikorupsi memperoleh jumlah skor sebesar 69. Penilaian reviewer guru mata pelajaran PPKn pada aspek komponen pembelajaran yang ada pada modul pendidikan antikorupsi termasuk kategori baik. Sedangkan aspek komponen bahasa yang ada pada modul pendidikan antikorupsi memperoleh jumlah skor sebesar 20. Penilaian reviewer guru mata pelajaran PPKn pada aspek komponen bahasa yang ada pada modul pendidikan anti korupsi termasuk kategori baik. Pada aspek komponen penyajian media teks yang ada pada modul pendidikan antikorupsi memperoleh jumlah skor sebesar 62 dalam kategori baik. Sedangkan penilaian mengenai aspek kegrafikan yang ada pada modul pendidikan antikorupsi memperoleh jumlah skor sebesar 61 dalam kategori baik

\section{Data Reviewer Teman Sejawat}

Berdasarkan hasil validasi reviewer teman sejawat menunjukkan bahwa aspek komponen kelayakan isi materi yang ada pada modul pendidikan antikorupsi memperoleh jumlah skor sebesar 47 dalam kategori sangat baik. sedangkan aspek komponen pembelajaran yang ada pada modul pendidikan antikorupsi memperoleh jumlah skor sebesar 82 dalam kategori sangat baik. Pada aspek komponen bahasa modul pendidikan antikorupsi memperoleh jumlah skor sebesar 25 dengan kategori sangat baik. Sedangkan aspek komponen penyajian media teks mendapatkan skor 30.

Penilaian reviewer teman sejawat pada aspek komponen penyajian teks yang ada pada modul pendidikan anti korupsi termasuk kategori sangat baik. Pada aspek kegrafikan modul pendidikan anti korupsi memperoleh jumlah skor sebesar 71. Penilaian reviewer teman sejawat pada aspek komponen kegrafikan yang ada pada modul pendidikan antikorupsi termasuk kategori baik. dalam kategori sangat baik. Perbandingan penilaian reviewer modul pendidikan anti korupsi dapat dilihat pada gambar 1. 


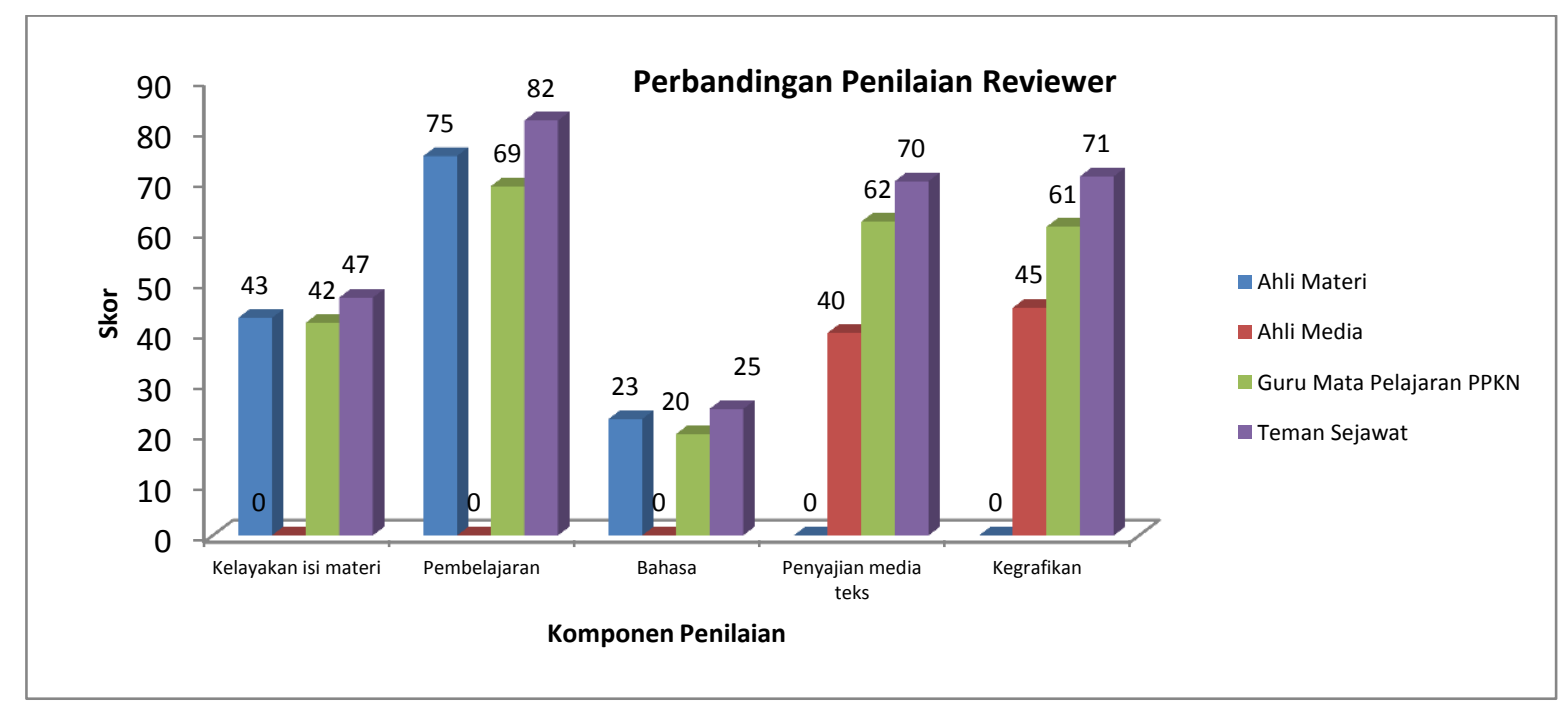

Gambar 1. Perbandingan Penilaian Reviewer

Gambar 1 menunjukkan bahwa pada aspek komponen kelayakan isi materi pada reviewer ahli media memperoleh skor 40, reviewer guru mata pelajaran PPKn memperoleh skor 42 dan reviewer teman sejawat memperoleh skor 47. Aspek komponen pembelajaran pada reviewer ahli materi memperoleh skor 75 , reviewer guru mata pelajaran PPKn memperoleh skor 69, reviewer teman sejawat sebesar 82. Aspek bahasa pada penilaian reviewer ahli materi sebesar 23, reviewer guru mata pelajaran PPKn sebesar 20 dan reviewer teman sejawat sebesar 25 . Aspek penyajian media teks pada penilaian reviewer ahli media sebesar 40 , reviewer guru mata pelajaran PPKn sebesar 62, dan reviewer teman sejawat sebesar 70. Aspek kegrafikan pada penilaian reviewer ahli media sebesar 45, reviewer guru mata pelajaran PPKn sebesar 61, dan reviewer teman sejawat sebesar 71. Dengan demikian, seluruh komponen penilaian dalam modul pendidikan antikorupsi memperoleh skor tertinggi oleh reviewer teman sejawat.

\section{Data Uji Coba Kelompok Kecil}

Uji coba lapangan skala kecil dilakukan setelah melalui proses validasi oleh ahli media, ahli materi, reviewer guru mata pelajaran PPKn dan reviewer teman sejawat. Uji coba skala kecil dilakukan oleh 7 peserta didik SMA Muhammadiyah I Ponorogo perwakilan masing-masing 1 dari kelas X IPA 1 ,
X IPA 2, X IPA 4, X IPA 6, X IPS 1, X IPS 2, dan X IPS 3. Uji coba skala kecil dilakukan untuk mengetahui permasalahan dan kekurangan modul, sehingga dapat disempurnakan lagi. Uji coba skala kecil menggunakan angket dengan skala Likert dengan alternatif jawaban "sangat baik', "baik","cukup", "kurang", dan "sangat kurang". Angket terdiri dari 27 butir pernyataan. Aspek materi terdiri dari 10 pernyataan, aspek karakteristik tampilan modul terdiri dari 6 pernyataan dan aspek media terdiri dari 17 pernataan. Data uji coba terbatas pada uji coba skala kecil perwakilan peserta didik disajikan pada Tabel 1.

Tabel 1. Perbandingan Penilaian Uji Coba Skala Kecil

\begin{tabular}{ccl}
\hline Peserta didik & Skor & \multicolumn{1}{c}{ Kategori } \\
\hline X IPA 1 & 101 & Baik \\
X IPA 2 & 101 & Baik \\
X IPA 4 & 124 & Sangat Baik \\
X IPA 6 & 119 & Sangat Baik \\
X IPS 1 & 119 & Sangat Baik \\
X IPS 2 & 92 & Baik \\
X IPA 3 & 135 & Baik \\
Rata-rata & 113 & Baik \\
\hline
\end{tabular}

Dari Tabel 1 menunjukkan bahwa data uji coba terbatas memperoleh skor ratarata sebesar 113. Dengan demikian modul pendidikan antikorupsi berdasarkan penilaian uji coba skala kecil dalam kategori baik. 
Perbandingan skor uji coba kelompok kecil dapat dilihat pada Gambar 2.

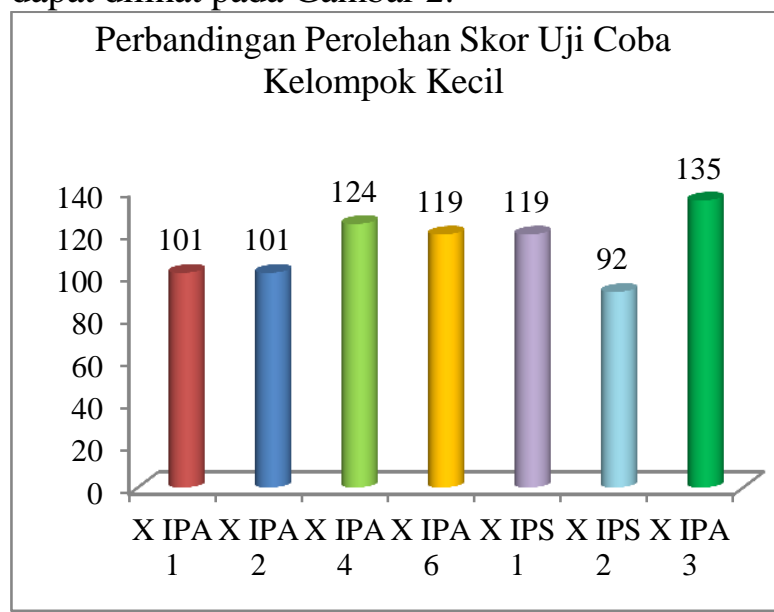

Gambar 2. Perbandingan Penilaian Uji Coba

$$
\text { Kelompok Kecil }
$$

\section{Data Uji Coba Lapangan}

Uji coba lapangan untuk mengetahui keefektifan modul pendidikan anti korupsi terhadap hasil belajar dan sikap anti korupsi pada peserta didik SMA Muhammadiyah I Ponorogo.

\section{Hasil Belajar}

Data hasil belajar dalam penelitian ini menghasilkan dua macam data, yaitu data skor pretest dan data skor postest pem-belajaran PPKn baik pada kelas kontrol maupun kelas eksperimen. Pada kelas eksperimen, tes tersebut untuk membandingkan hasil pembelajaran PPKn pada peserta didik kelas X IPA 3 SMA Muhammadiyah Ponorogo sebelum dan sesudah menggunakan modul pendidikan anti korupsi. Hasil penelitian pada kelas eksperimen (menggunakan modul pendidikan anti korupsi) dan kelas kontrol (tidak menggunakan modul pendidikan anti korupsi) disajikan sebagai berikut.

\section{Data Pre-test Kelas Eksperimen}

Kelas eksperimen merupakan kelas yang diajar dengan menggunakan media maudul pendidikan anti korupsi. Sebelum dilakukan pembelajaran dengan menggunakan modul pendidikan anti korupsi, terlebih dahulu dilakukan pretest, untuk mengetahui kemampuan belajar peserta didik sebelum dilakukan pembelajaran dengan menggunakan media modul pendidikan anti korupsi. Subjek pada pretest kelas eksperimen sebanyak 30 peserta didik.

Adapun hasil pre-test kelas eksperimen nilai terendah adalah 27 dan nilai tertinggi sebesar 73 . Nilai mean sebesar 50.47 , nilai median sebesar 50.00 dan nilai modus sebesar 47.00. Berdasarkan hasil pre-test eksperimen yang telah dilakukan dapat diketahui ketuntasan pembelajaran PPKn yang disajikan pada Tabel 2.

Tabel 2. Persentase Ketuntasan Pembelajaran PPKn Pre-test Eksperimen

\begin{tabular}{ccccc}
\hline No & Kriteria & Kategori & Frekuensi & Persentase \\
\hline 1 & $<78$ & Belum & 30 & $100,0 \%$ \\
& \multicolumn{5}{c}{ Tuntas } \\
2 & $\geq 78$ & Tuntas & 0 & $0 \%$ \\
\multicolumn{2}{c}{ Jumlah } & 30 & $100,0 \%$ \\
\hline
\end{tabular}

Hasil pre-test pada kelas eksperimen di atas menunjukkan bahwa seluruh peserta didik $(100,0 \%)$ mendapatkan nilai di bawah standar kriteria nilai ketuntasan minimal (KKM) yang ditentukan oleh guru, yaitu 78 . Sementara peserta didik yang dalam kategori tuntas tidak ada.

\section{Data Post-test Kelas Eksperimen}

Subjek pada post-test kelompok eksperiemen sebanyak 30 peserta didik dari tes akhir, skor terendah adalah 53 dan skor tertinggi yang dicapai peserta didik adalah 87 . Nilai mean sebesar 73.07, nilai median sebesar 73.00 dan nilai modus sebesar 80.00. Berdasarkan hasil post-test yang telah dilakukan dapat diketahui ketuntasan pembelajaran PPKn yang disajikan pada tabel 3 .

Tabel 3. Persentase ketuntasan pembelajaran PPKn Post-test Eksperimen

\begin{tabular}{|c|c|c|c|c|}
\hline No & Kriteria & Kategori & Frekuensi & Persentase \\
\hline 1 & $<78$ & Belum & 17 & $56,7 \%$ \\
\hline & & Tuntas & & \\
\hline 2 & $\geq 78$ & Tuntas & 13 & $43,3 \%$ \\
\hline \multicolumn{3}{|c|}{ Jumlah } & 30 & $100,0 \%$ \\
\hline
\end{tabular}

Hasil post-test pada kelas eksperimen menunjukkan bahwa terdapat 17 peserta didik $(56,7 \%)$ dalam kategori belum tuntas. Sementara peserta didik yang tuntas sebanyak 13 peserta didik $(43,3 \%)$. Hal ini berarti terjadi peningkatan yang sebelumnya pada saat pre- 
test seluruh peserta didik dalam kategori belum tuntas.

\section{Data Pre-test Kelas Kontrol}

Kelas kontrol merupakan kelas yang diajar tanpa menggunakan modul pendidikan anti korupsi. Sebelum kelas kontrol diberikan perlakuan, terlebih dahulu dilakukan pretest hasil belajar PPKn. Subjek pada pre-test kelas kontrol sebanyak 27 peserta didik. Dari hasil belajar awal, skor tertinggi yang dicapai peserta didik adalah 73 dan skor terendah sebesar 27. Nilai mean sebesar 53.37, nilai median sebesar 53.00 dan nilai modus sebesar 53.00.

Berdasarkan hasil pre-test kelas kontrol yang telah dilakukan dapat diketahui ketuntasan pembelajaran PPKn yang disajikan pada Tabel 4.

Tabel 4. Persentase Ketuntasan Pembelajaran PPKn Pre-test Kontrol

\begin{tabular}{|c|c|c|c|c|}
\hline No & Kriteria & Kategori & Frekuensi & Persentase \\
\hline 1 & $<78$ & Belum & 27 & $100,0 \%$ \\
\hline & & Tuntas & & \\
\hline 2 & $\geq 78$ & Tuntas & 0 & $0 \%$ \\
\hline \multicolumn{3}{|c|}{ Jumlah } & 27 & $100,0 \%$ \\
\hline
\end{tabular}

Hasil pre-test pada kelas kontrol di atas menunjukkan bahwa terdapat 27 peserta didik $(100 \%)$ dalam kategori belum tuntas atau nilai di bawah standar kriteria nilai ketuntasan minimal (KKM) yang ditentukan oleh guru, yaitu 78. Sementara peserta didik dalam kategori tuntas tidak ada.

\section{Data Post-test Kelas Kontrol}

Pemberian post-test hasil belajar PPKn kelas kontrol dilakukan untuk melihat pencapaian peningkatan hasil belajar PPKn tanpa menggunakan modul pendidikan antikorupsi. Subjek pada post-test kelas kontrol sebanyak 27 peserta didik. Dari hasil tes akhir (postest), skor tertinggi yang dicapai peserta didik adalah 80 dan skor terendah adalah 47 . Nilai mean sebesar 63,92 , nilai median sebesar 60.00 dan nilai modus sebesar 60.00 .

Berdasarkan hasil post-test kelas kontrol yang telah dilakukan dapat diketahui ketuntasan pembelajaran PPKn yang disajikan pada Tabel 5.

Hasil post-test pada kelas kontrol di atas menunjukkan bahwa terdapat 23 peserta didik $(85,2 \%)$ mendapatkan nilai di bawah standar kriteria nilai ketuntasan minimal (KKM) yang ditentukan oleh guru, yaitu 78 . Sementara peserta didik yang tuntas sebanyak 4 peserta didik $(14,8 \%)$. Perbandingan nilai pre-test dan post-test kelas eksperimen dan kelas kontrol dapat dilihat pada gambar 3

Tabel 5. Persentase Ketuntasan Pembelajaran PPKn Post-test Kontrol

\begin{tabular}{ccccc}
\hline No & Kriteria & Kategori & Frekuensi & Persentase \\
\hline 1 & $<78$ & Belum & 23 & $85,2 \%$ \\
& & Tuntas & & \\
2 & $\geq 78$ & Tuntas & 4 & $14,8 \%$ \\
& \multirow{2}{*}{ Jumlah } & 27 & $100,0 \%$ \\
\hline
\end{tabular}

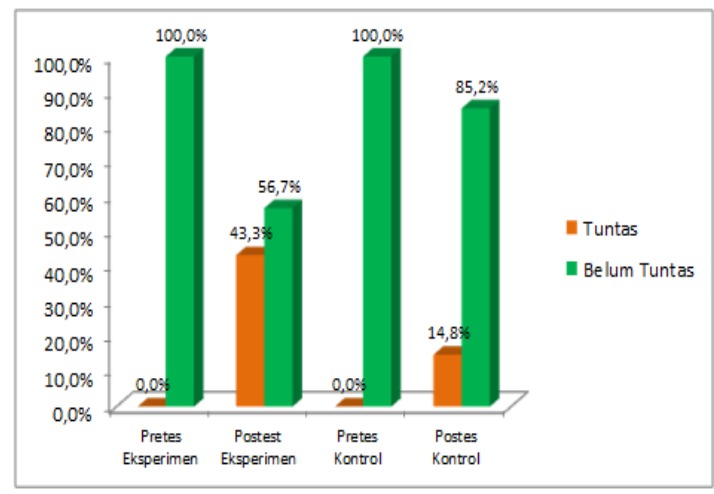

Gambar 3. Perbandingan nilai pre-test dan posttest kelas eksperimen dan kelas kontrol

Kelas eksperimen saat pretes seluruhnya dalam kategori belum tuntas $(100 \%)$. Setelah menggunakan modul pendidikan anti korupsi dalam pembelajaran PPKn terdapat sebanyak 43,3\% peserta didik dalam kategori tuntas. Sementara hasil belajar peserta didik pada kelas kontrol saat pretes seluruhnya dalam kategori belum tuntas $(100 \%)$. Setelah post-test tanpa menggunakan modul pendidikan antikorupsi dalam pembelajaran PPKn hanya $14,8 \%$ peserta didik dalam kategori tuntas.

\section{Sikap Antikorupsi}

Data hasil sikap antikorupsi peserta didik diperoleh melalui lembar observasi dengan 10 aspek penilaian yang meliputi berdoa dan memberikan salam, kejujuran, kepeduli- 
an, kemandirian, kedisiplinan, tanggung jawab, kerja keras, kesederhanaan, keberanian, dan keadilan.

\section{Kelas Eksperimen}

Berdasarkan data sikap Antikorupsi menggunakan modul pendidikan anti korupsi yang diolah menggunakan program SPSS, maka diperoleh skor tertinggi sebesar 96.00 dan skor terendah sebesar 66.00. Hasil analisis menunjukkan rerata (mean) sebesar 79.93, median 79.00, modus 76.00 dan standar deviasi sebesar 7.09.

Kemudian penentuan kecenderungan sikap antikorupsi peserta didik, setelah nilai minimum (Xmin) dan nilai maksimum (Xmax) diketahui yaitu 0 dan 100 , maka selanjutnya mencari nilai rata-rata ideal (Mi) dengan rumus $\mathrm{Mi}=1 / 2(X \max +\mathrm{Xmin})$, mencari standar deviasi ideal $(\mathrm{SDi})$ dengan rumus $\mathrm{Sdi}=1 / 6$ (Xmax-Xmin). Berdasarkan acuan norma di atas, mean ideal variabel sikap anti korupsi peserta didik pada kelas eksperimen adalah 50. Standar deviasi ideal adalah 16,67. Dari perhitungan di atas dapat dikategorikan dalam 5 kelas sebagai berikut.

Sangat Baik : $X>M+1,5 \mathrm{SD}$

Baik $\quad: M+0,5 \mathrm{SD}<\mathrm{X} \leq \mathrm{M}+1,5 \mathrm{SD}$

Cukup Baik : $\mathrm{M}-0,5 \mathrm{SD}<\mathrm{X} \leq \mathrm{M}+0,5 \mathrm{SD}$

Kurang Baik : $\mathrm{M}-1,5 \mathrm{SD}<\mathrm{X} \leq \mathrm{M}-0,5 \mathrm{SD}$

Sangat Kurang Baik : $\mathrm{X} \leq \mathrm{M}-1,5 \mathrm{SD}$

Berdasarkan kategorisasi tersebut dapat dibuat tabel distribusi sikap antikorupsi peserta didik menggunakan modul pendidikan antikorupsi kelas eksperimen yang disajikan pada Tabel 6.

Tabel 6. Sikap Anti korupsi Peserta didik Menggunakan Modul Pendidikan Anti korupsi Kelas Eksperiemen

\begin{tabular}{ccccl}
\hline \multirow{2}{*}{ No } & \multirow{2}{*}{ Skor } & \multicolumn{2}{c}{ Frekuensi } & \multirow{2}{*}{ Kategori } \\
& & Frek & $\%$ & \\
\hline 1 & $\geq 81$ & 10 & $33,3 \%$ & Sangat Baik \\
2 & $61-80$ & 20 & $66,7 \%$ & Baik \\
3 & $41-60$ & 0 & $0 \%$ & Cukup Baik \\
4 & $21-40$ & 0 & $0 \%$ & Kurang Baik \\
5 & $<20$ & 0 & $0 \%$ & Sangat Kurang Baik \\
& Total & 30 & 100,0 & \\
\hline
\end{tabular}

Berdasarkan Tabel 6 menunjukkan kecenderungan sikap antikorupsi peserta didik dengan modul pendidikan antikorupsi pada kategori baik sebesar $66,7 \%$ dan kategori sangat baik sebesar 33,3\%. Dengan demikian dari hasil yang diperoleh dapat dikatakan bahwa mayoritas kecenderungan sikap antikorupsi peserta didik dengan modul pendidikan anti korupsi pada kategori baik. Kecenderungan sikap anti korupsi peserta didik kelas eksperimen dapat dilihat dalam pada Gambar 4.

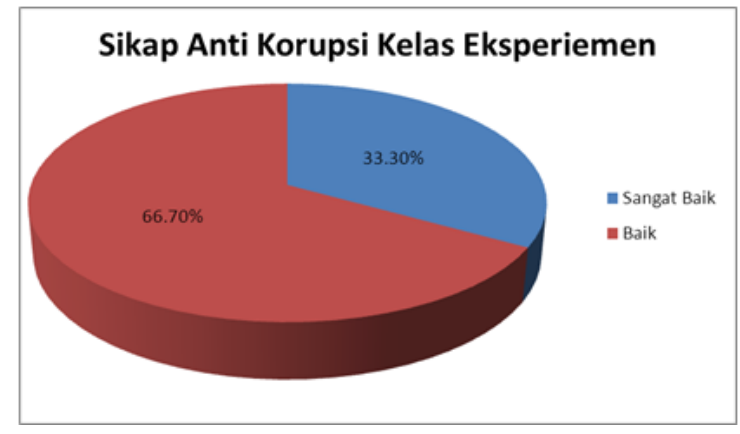

Gambar 4. Diagram Pie Kecenderungan Sikap Anti korupsi Peserta didik Kelas Eksperieme

Kelas Kontrol

Berdasarkan data sikap antikorupsi peserta didik tanpa menggunakan modul pendidikan antikorupsi yang diolah menggunakan program SPSS, maka diperoleh skor tertinggi sebesar 86.00 dan skor terendah sebesar 62.00. Hasil analisis menunjukkan rerata (mean) sebesar 71.00, median 71.00, modus 72.00 dan standar deviasi sebesar 6.22. Kemudian penentuan kecenderungan sikap anti korupsi peserta didik, setelah nilai minimum (Xmin) dan nilai maksimum (Xmax) diketahui yaitu 0 dan 100, maka selanjutnya mencari nilai rata-rata ideal $(\mathrm{Mi})$ dengan rumus $\mathrm{Mi}=$ $1 / 2$ (Xmax+Xmin), mencari standar deviasi ideal (SDi) dengan rumus Sdi $=1 / 6$ (XmaxXmin). Berdasarkan acuan norma di atas, mean ideal variabel sikap anti korupsi peserta didik pada kelas eksperimen adalah 50. Standar deviasi ideal adalah 16,67. Dari perhitungan di atas dapat dikategorikan dalam 5 kelas sebagai berikut.

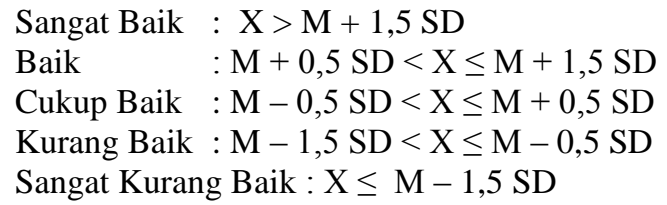


Berdasarkan perhitungan tersebut dapat dibuat tabel distribusi sikap anti korupsi peserta didik tanpa menggunakan modul pendidikan anti korupsi kelas kontrol yang disajikan pada Tabel 7.

Tabel 7. Kecenderungan Sikap Anti korupsi Peserta didik Kelas Kontrol

\begin{tabular}{ccccl}
\hline \multirow{2}{*}{ No } & \multirow{2}{*}{ Skor } & \multicolumn{2}{c}{ Frekuensi } & \multirow{2}{*}{ Kategori } \\
& & Frek & $\%$ & \\
\hline 1 & $\geq 81$ & 4 & $14,8 \%$ & Sangat Baik \\
2 & $61-80$ & 23 & $85,2 \%$ & Baik \\
3 & $41-60$ & 0 & $0 \%$ & Cukup Baik \\
4 & $21-40$ & 0 & $0 \%$ & Kurang Baik \\
5 & $<20$ & 0 & $0 \%$ & Sangat Kurang Baik \\
\multicolumn{2}{c}{ Total } & 27 & 100,0 & \\
\hline
\end{tabular}

Berdasarkan tabel 7 menunjukkan kecenderungan sikap anti korupsi peserta didik tanpa menggunakan modul pendidikan anti korupsi pada kategori baik sebanyak 23 peserta didik $(85,2 \%)$ dan kategori sangat baik sebanyak 4 peserta didik (14,8\%). Dengan demikian dari hasil yang diperoleh di atas dapat dikatakan bahwa kecenderungan sikap anti korupsi peserta didik pada kelas kontrol dalam kategori baik. Kecenderungan sikap anti korupsi peserta didik kelas kontrol dapat dilihat pada Gambar 5.

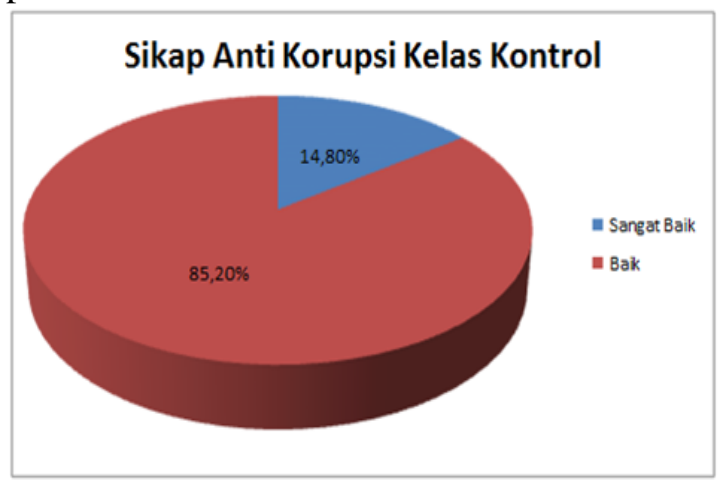

Gambar 5. Sikap Antikorupsi Kelas Kontrol

\section{Simpulan}

Berdasarkan hasil penelitian dan pembahasan yang telah diuraikan, maka dapat disampaikan simpulan sebagai berikut. Pengembangan media menghasilkan modul pendidikan antikorupsi yang layah pada mata pelajaran PPKn. Penentuan kelayakan modul pendidikan antikorupsi melalu beberapa tahapan, meliputi, validasi ahli materi, ahli me- dia, guru PPKn dan teman sejawat serta uji kelompok kecil. Pada tahapan ahli materi komponen kelayakan materi mendapatkan kategori baik, sedangkan komponen pembelajaran dan bahasa dengan kategori sangat baik. Ahli media dengan komponen penyajian media teks dengan kategori kurang baik sedang pada komponen kegrafikan cukup baik. Pada tahap guru mata pelajaran PPKn dari kelima komponen penilaian mendapat kategori baik. Untuk tahap teman sejawat dari kelima komponen dengan kategori sangat baik. Sedangkan pada tahapan uji kelompok kecil dengan jumlah 7 peserta didik mewakili dari tiap kelas $\mathrm{X}$ menunjukkan bahwa sebanyak $42,86 \%$ peserta didik menyatakan modul pendidikan antikorupsi pada kategori baik dan $57,14 \%$ peserta didik menyatakan pada kategori sangat baik. Dengan demikian dapat diartikan modul telah memenuhi kelayakan dangan kategori baik dan dapat digunakan sebagai media pembelajaran.

Modul pendidikan antikorupsi efektif pada hasil belajar peserta didik di SMA. Hal ini ditunjukkan dengan perolehan gain score dan peningkatan nilai mean. Peserta didik yang menggunakan modul pendidikan anti-korupsi memperoleh gain score sebesar 0,44 dalam kategori efektivitas sedang. Sementara peserta didik yang tanpa menggunakan modul pendidikan antikorupsi memperoleh gain score sebesar 0,20 dalam kategori efektivitas rendah. Nilai mean peserta didik yang meng-gunakan modul meningkat sebesar $46.00 \%$ yakni pada saat pretest sebesar 50.00 menjadi 73.00 saat postest.

Modul pendidikan antikorupsi efektif pada sikap antikorupsi peserta didik di SMA. Hal ini ditunjukkan dengan perolehan gain score dan peningkatan skor mean. Sikap antikorupsi pada peserta didik yang menggunakan modul pendidikan antikorupsi memperoleh gain score sebesar 0,80 dalam kategori efektivitas tinggi. Sementara sikap antikorupsi peserta didik yang tanpa menggunakan modul pendidikan antikorupsi memperoleh gain score sebesar 0,70 dalam kategori efektivitas sedang. Skor mean peserta didik yang menggunakan modul pendidikan antikorupsi sebesar 80, sedangkan yang tanpa modul sebesar 70 .

Saran yang dapat disampaikan dari simpulan penelitian adalah sebagai berikut. Peserta didik dapat memanfaatkan modul pen- 
didikan antikorupsi sebagai media pembelajaran pada mata pelajaran PPKn khususnya tentang materi hukum dan peradilan di Indonesia pada kelas X SMA. Alangkah lebih baik jika guru tidak hanya memanfaatkan media modul tersebut tetapi juga belajar untuk membuat media modul sendiri pada materi yang lainnya, sehingga dapat meningkatkan kualitas pembelajaran PPKn.

Hendaknya pihak sekolah mengadakan pelatihan pembuatan media pembelajaran khususnya media modul agar guru dalam mengajar tidak menggunakan media yang monoton. Lebih baik lagi jika pihak sekolah membuat kebijakan untuk memanfaatkan dan membuat media dalam pembelajaran sesuai kurikulum yang dapat mendukung kualitas pembelajaran

Pada peneliti selanjutnya dapat mengembangkan modul pendidikan antikorupsi dengan melengkapi keterbatasan yang ada dalam penelitian ini. Misalnya mengembangkan komponen penyajian media teks yang dalam penelitian ini menurut reviewer ahli media masih dalam kategori kurang baik dan perlu adanya reviewer ahli bahasa

\section{Daftar Pustaka}

Depdiknas. (2014). Buku guru pendidikan pancasila dan kewarganegaraan sekolah menenggah atas. Jakarta: Depdiknas.

Hakim, L. (2012). Model integrasi pendidikan anti korupsi dalam kurikulum pendidikan islam. Jurnal Pendidikan Agama Islam-Ta'lim, 10(2). Retrieved from http://jurnal.upi.edu/file/04_Model_Integ rasi_Pendidikan_Anti_KorupsiLukman_Hakim.pdf

Mukodi, \& Buhanuddin, A. (2014). Pendidikan anti korupsi: rekonstruksi interpretatif dan aplikatif di sekolah.
Yogyakarta: Aura Pustaka, kerjasama dengan LPPM STKIP Pacitan.

Murwantono, \& Sukidjo. (2015). Peningkatan hasil belajar IPS dengan model problem based learning berbantuan media stimulan gambar. Harmoni Sosial: Jurnal Pendidikan IPS, 2(1). Retrieved from https://journal.uny.ac.id/index.php/hsjpi/ article/view/4601

Republik Indonesia. MPR/1998 tentang penyelenggaraan negara yang bersih dan bebas korupsi (1998).

Republik Indonesia. Undang Undang No. 8 Tahun 1999 tentang penyelenggara negara yang bersih dan bebas dari korupsi, kolusi, dan nepotisme (1999).

Republik Indonesia. Undang-Undang No. 30 Tahun 2002 tentang korupsi maka dibentuklah Komisi Pemberantasan Korupsi (KPK). (2002).

Sax, G. (1993). Princeples of educational and psychological meansurement and evaluation. Washington: Wadsworth Publishing Company.

Svensson, J. (2005). Eight Questions about Corruption. Journal of Economic Perspectives, 19(3), 19-42. https://doi.org/10.1257/08953300577435 7860

Van Dyne, L., \& LePine, J. A. (1998). Helping and Voice Extra-Role Behaviors: Evidence of Construct and Predictive Validity. The Academy of Management Journal, 41(1), 108-119. https://doi.org/10.2307/256902

Vembriarto. (1985). Pengantar pengajaran modul. Yogyakarta: Yayasan Pendidikan Paramita. 